\title{
Filterisasi Noise Pada Citra Uang Logam Indonesia
}

\author{
Meirista Wulandari ${ }^{1}$
}

\begin{abstract}
Images are familiar to the computer sciences and application systems. Image or another term for the image is one multimedia component that plays an important role as a form of visual information The image consists of a set of data that contains a lot of information. Images that contain a lot of information can sometimes experience quality degradation as there is noise, color is too contrast or blur, and others. In this study will be compared the value of MSE and PSNR filter coin image 500 given noise. There are 3 sounds attached to the image of 500 coins namely Exponential, Gaussian, and Salt and Pepper noises. After coin image 500 is given noise, filtering process is done. The filter used in this study there are 3 types of filters are Average, Median and Wiener. The value of MSE and PSNR is obtained from the comparison between the image of the filtering result and the image before it is given noise. Testing is done by comparing the values of MSE and PSNR on each given image and then searching for the best filter among the mean, Median, and Wiener filters. Test results showed that the Wiener filter had the lowest MSE value and the highest PSNR for each filtered noise. Based on the results of the Wiener filter test is the best filter that can be used for the filtering process of Gaussian Exponential noise and Salt and Pepper compared with the average filter and Median.
\end{abstract}

Keywords: Images, Noise, Filter.

\begin{abstract}
ABSTRAK: Gambar atau citra sudah tidak asing. Citra atau istilah lain untuk gambar merupakan salah satu komponen multimedia yang berperan penting sebagai bentuk informasi visual Citra terdiri dari sekumpulan data yang mengandung banyak informasi. Citra yang mengandung banyak informasi terkadang dapat mengalami penurunan kualitas seperti terdapat derau, warna terlalu kontras atau kabur, dan lain-lain. Dalam penelitian ini akan dibandingkan nilai MSE dan PSNR filter citra koin 500 yang diberikan derau. Terdapat 3 derau yang diberikkan pada citra koin 500 yaitu derau Eksponensial, Gaussian, dan Salt and Pepper. Setelah citra koin 500 diberikan derau, dilakukan proses filtering. Filter yang digunakan pada penelitian ini ada 3 jenis yaitu filter Rerata, Median dan Wiener. Nilai MSE dan PSNR didapatkan dari perbandingan antara citra hasil filtering dengan citra sebelum diberikan derau. Pengujian dilakukan dengan membandingkan nilai MSE dan PSNR pada setiap citra yang diberikan kemudian mencari filter yang terbaik diantara filter Rerata, Median, dan Wiener. Hasil Pengujian didapatkan bahwa filter Wiener mempunya nilai MSE terendah dan PSNR tertinggi untuk setiap derau yang difilter. Berdasarkan hasil pengujian filter Wiener merupakan filter terbaik yang dapat digunakan untuk proses filtering derau Gaussian Eksponensial dan Salt and Pepper dibandingkan dengan filter Rerata dan Median.
\end{abstract}

Kata Kunci : Citra, Derau, Filter

\section{PENDAHULUAN}

$\mathrm{G}$ ambar atau citra sudah tidak asing lagi di telinga kita. Citra atau istilah lain untuk gambar merupakan salah satu komponen multimedia yang berperan penting sebagai bentuk informasi visual[1]. Pada dasarnya citra dibagi menjadi 2 macam, yaitu citra digital dan citra analog. Seiring berjalannya waktu, citra digital lebih banyak digunakkan dari pada citra analog. Hal tersebut disebabkan karena citra digital memiliki kelebihan seperti pengiriman data dan pengolahan data yang mudah.

Citra terdiri dari sekumpulan data yang mengandung banyak informasi. Citra yang mengandung banyak informasi terkadang dapat mengalami penurunan kualitas seperti terdapat derau, warna terlalu kontras atau kabur, dan lain-lain. Penurunan kualitas citra dapat terjadi pada saat proses pengambilan, pengiriman atau penyimpanan data. Penurunan kualitas citra menyebabkan informasi yang terdapat dalam citra berubah dan tidak sesuai yang diharapkan. Untuk mengatasi hal ini, perlu dilakukan proses filtering agar mendapatkan hasil citra yang maksimal.

Dalam penelitian kali ini dilakukan perbandingan filter untuk mencari tahu filter yang terbaik. Filter yang dibandingkan terdiri dari filter Rerata, Median, dan Wiener. Terdapat beberapa koin pada mata uang logam rupiah yaitu Rp. 200,00, Rp. 500,00 dan Rp. 1.000,00. Ketiga filter tersebut akan diterapkan pada citra koin yang diambil dari jarak tertentu. Citra koin yang digunakan pada penelitian ini adalah koin Rp. 500,00 (dianggap koin ini merupakan pecahan yang umum digunakan dalam kehidupan sehari-hari) yang diberikan derau sebelumnya. Terdapat 3 derau yang diberikan pada citra koin 500 yaitu derau Salt and Pepper, Gaussian dan, Eksponensial. Proses pemberian derau hingga filtering akan dilakukan menggunakan software Matlab 2017

\section{METODE PENELITIAN}

\section{$1 \quad$ Landasan Teori}

Citra (image) merupakan istilah lain untuk gambar sebagai bentuk informasi visual, yang memegang peranan penting dan merupakan salah satu komponen multimedia. Citra dapat diukur melalui pendapat, kesan atau respon seseorang dengan tujuan untuk mengetahui secara pasti apa yang ada dalam pikiran setiap individu mengenai suatu objek. Suatu citra dapat memiliki suatu makna yang sangat kaya atau sederhana saja

\subsection{Citra Digital}

Citra digital adalah citra 2 dimensi yang dihasilkan dari citra analog yang kontinyu menjadi gambar diskret melalui proses digitalisasi. Sedangkan citra analog merupakan citra yang dibagi menjadi $\mathrm{M}$ baris dan $\mathrm{N}$ kolom

\footnotetext{
${ }^{1}$ Program Studi Teknik Elektro, Fakultas Teknik, Universitas Tarumanagara
} 
sehingga menjadi diskret. Persilangan antara baris dan kolom disebut dengan piksel. Berdasarkan pikselnya, citra dibagi menjadi 2 yaitu citra RGB dan citra Grayscale

\subsubsection{Citra RGB}

Citra RGB merupakan citra yang setiap pikselnya diwakili oleh kombinasi tiga warna dasar, yaitu merah, hijau, dan biru (RGB = Red, Green, Blue). Setiap warna dasar menggunakan penyimpanan 8 bit $=1$ byte (nilai maksimum 255 warna), jadi satu piksel pada citra warna diwakili oleh 3 byte.

\subsubsection{Citra Grayscale}

Citra grayscale merupakan citra yang mempunyai kemungkinan warna hitam untuk nilai minimal dan warna putih untuk nilai maksimal. Banyaknya warna tergantung pada jumlah bit yang disediakan di memori untuk menampung kebutuhan warna tersebut. Semakin besar jumlah bit warna yang disediakan di memori, maka semakin halus gradasi warna yang terbentuk

\subsection{Spatial Filtering}

Spatial filter merupakan filter yang meng-konvolusi suatu citra dengan citra lain. Spatial filtering dapat dianggap sebagai suatu konsep modifikasi nilai piksel citra digital dengan menerapkan suatu fungsi pada piksel tetangga dari piksel tersebut. Terdapat 3 jenis Spatial filtering yang digunakan yaitu Filter Rerata ( Mean Filtering ), Filter Median (Median filtering), dan Filter Wiener (Wiener Filtering).

\subsubsection{Mean Filtering}

Mean Filter adalah mengganti nilai piksel pada posisi (x,y) dengan nilai rata-rata piksel yang berada tetangga disekitarnya. Luasan jumlah piksel tetangga ditentukan sebagai masking/kernel/window yang berukuran misalkan $2 \times 2,3 \times 3,4 \times 4$, dan seterusnya. Kemudian akan dilakukan mean filter untuk citra $\mathrm{M}$ dengan menggunakan matriks kernel (3x3). Piksel $\mathrm{m}(2,2)=3$, akan diubah menjadi Selain mean filtering yang merupakan proses filter linier[3].

\subsubsection{Median Filtering}

Filter ini merupakan suatu filter non linear yang dikembangkan oleh Tukey. Pada Median Filter, suatu "window" yang memuat sejumlah piksel ganjil digeserkan titik per titik pada seluruh daerah citra. Filter ini bekerja dengan menggantikan nilai tengah dari piksel yang dicakup oleh area filter dengan sebuah nilai tengah (Median) setelah diurutkan terlebih dahulu dari yang terkecil ke yang terbesar. Biasanya ukuran filter adalah ganjil karena akan memberikan poros tengah, sehingga akan lebih mudah dalam mengolah noise[3].

\subsubsection{Wiener Filtering}

Wiener Filter adalah filter yang akan melakukan penyaringan terhadap noise yang menyerang citra yang menyebabkan penurunan kualitas citra tersebut dengan menggunakan pendekatan statistik berdasarkan piksel-piksel tetangganya.

\subsection{Noise}

Pengertian noise Menurut kamus besar bahasa Inggris-Amerika "The American Heritage Dictionary of English Language, 4th Edition", dijelaskan bahwa noise adalah suara atau bunyi yang keras, tidak menyenangkan, tak terduga,atau tidak diinginkan [4]. Terdapat 3 Noise yang digunakan pada penelitian yaitu salt and pepper, gaussian, eksponensial.

\subsubsection{Salt and pepper noise}

Noise Salt and Pepper merupakan noise pada citra/image yang berupa titik-titik. Untuk citra gray scale, maka noise nya berupa warna hitam atau warna putih. Sedangkan untuk citra warna RGB, memiliki derau berupa warna red, green, atau blue. Untuk tingkat banyak sedikitnya noise pada citra ditentukan oleh nilai density (d) yang nilainya dalam rentang 0 sampai 1 .

\subsubsection{Gaussian Noise}

Noise Gaussian adalah noise yang mengikuti distribusi Gaussian. Noise Gaussian biasanya disebut juga White noise karena seluruh frekuensi spektral nya adalah sebagai cahaya putih. Besar sedikitnya noise ini ditentukan oleh nilai rata-rata (mean) dan nilai variasi. Besar nilainya bisa positif bisa juga negatif. Untuk nilai dasarnya, rata-rata(mean) nilainya adalah 0 dan untuk variasi (variance) nilai dasarnya adalah 0.01 . Semakin besar nilai rata-rata (mean) dan variasi (variance) nya, maka image hasil penambahan deraunya akan semakin kabur dan akan semakin mendekati putih warnanya. 


\subsubsection{Eksponensial Noise}

Exponensial Noise merupakan jenis noise yang dihasilkan oleh laser yang koheren ketika citra diperoleh. Oleh karena itu, noise ini sering disebut sebagai bercak laser.

\subsection{Mean Squared Error (MSE)}

RSME digunakan untuk mengukur tingkat error pada citra hasil filtering dengan membandingkannya dengan citra original. Untuk $f^{\prime}(x, y)$ adalah piksel citra hasil filtering, $f(x, y)$ adalah piksel citra original, $m$ adalah panjang citra dan $\mathrm{n}$ adalah lebar citra, RMSE dihitung dengan persamaan sebagai berikut :

$$
M S E=\frac{1}{M N} \sum_{x=0}^{M-1} \sum_{y=0}^{N-1} \mid\left(f(x, y)-g(x, y)^{2} \mid\right.
$$

\subsection{Peak Signal to Noise Ratio (PSNR)}

PSNR biasanya diukur dalam satuan desibel (db). PSNR digunakan untuk mengetahui perbandingan kualitas citra cover sebelum dan sesudah disisipkan pesan. Untuk menentukan PSNR, terlebih dahulu harus ditentukan nilai MSE (Mean Square Error) [5].

$$
P S N R=10 \log _{10} \frac{255^{2}}{M S E}
$$

\section{Metode}

Penelitian ini dilakukan menggunakan citra koin 500. Citra koin 500 merupakan citra digital 3 dimensi (RGB). Citra koin 5003 dimensi kemudian diubah menjadi 2 dimensi (Greyscale). Citra koin 5002 dimensi diberikkan derau. Terdapat 3 derau yang digunakkan pada penelitian ini yaitu derau Eksponensial, derau Gaussian, dan derau Salt and pepper. Citra koin yang sudah diberikkan ketiga derau dilakukan filter pada masingmasing derau. Terdapat 3 filter yang digunakkan pada penelitian ini yaitu filter Rerata, filter Median, dan filter Wiener. Proses pemberian derau hingga pemberian filter dilakukan dengan menggunakan software Matlab. Software Matlab dipilih karena penelitian ini cenderung menggunakan pendekatan melalui matriks citra untuk membandingkan citra asli sebelum pemberian derau dengan citra hasil filtering. Diagram alir penelitian dan arsitektur penelitian dapat dilihat pada Gambar 1. 


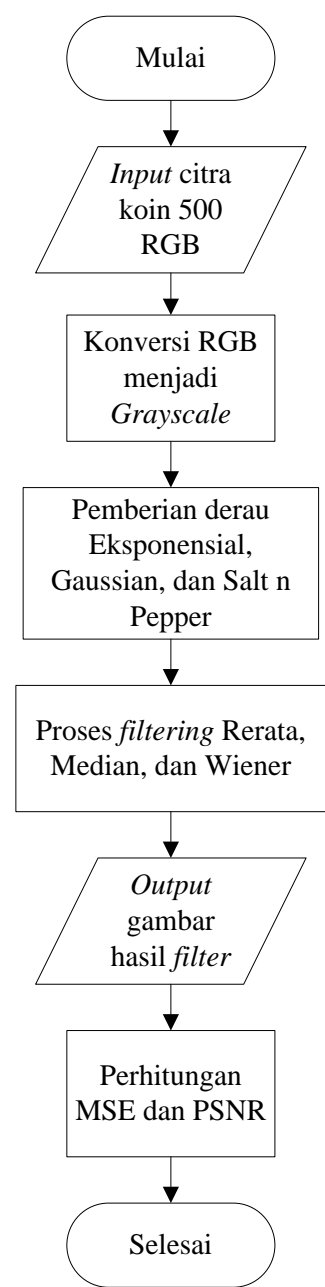

- Gambar 1 Diagram Alir Penelitian dan Arsitektur Penelitian

Proses pengolahan citra dalam penelitian ini terdiri dari input gambar citra koin 500, konversi RGB menjadi grayscale, pemberian derau, proses filtering, menghitung MSE dan PSNR. Semua proses tersebut akan dilakukan menggunakan software Matlab 2016a.

\subsection{Input Gambar Citra Koin 500}

Proses ini merupakan proses memasukkan gambar citra koin 500 ke dalam Matlab. Citra koin 500 yang dimasukkan merupakan citra digital 3 dimensi. Citra koin 500 yang dimasukkan berukuran 128 x 128 piksel. Terdapat 20 citra koin 500 berbeda yang digunakan dalam penelitian ini. Gambar salah satu citra koin 500 dapat dilihat pada Gambar 2.

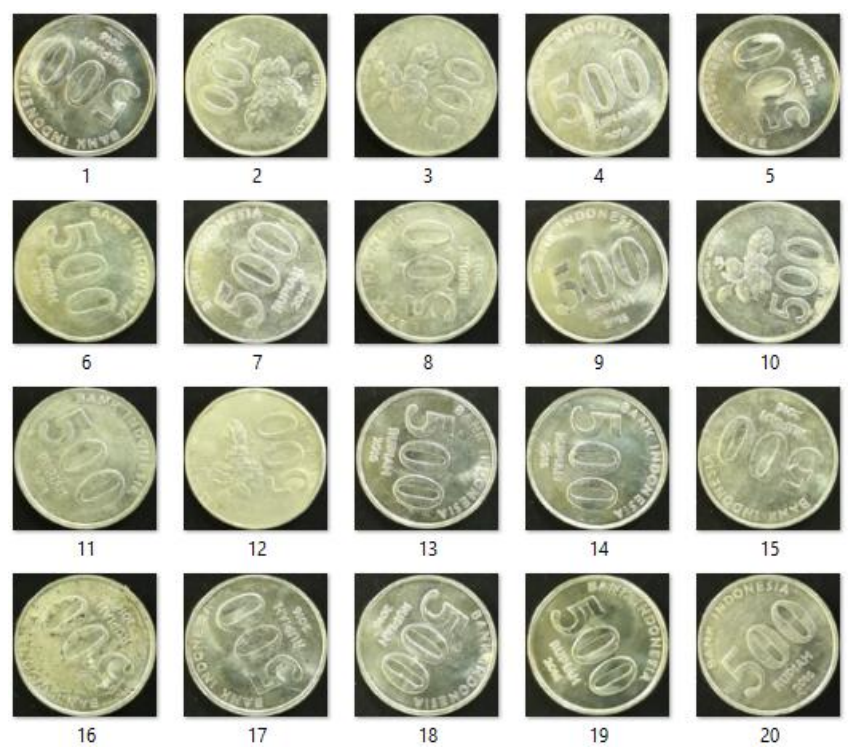

- Gambar 2 Citra Koin 500 


\subsection{Konversi RGB Menjadi Grayscale}

Citra koin yang dimasukkan pada proses 2.1 merupakan citra 3 dimensi yang setiap pikselnya mempunya nilai RGB. Citra tersebut akan diubah kedalam grayscale menggunakan fungsi Matlab rgb2gray. Konversi RGB menjadi grayscale dilakukan pada setiap citra koin 500 yang ada. Konversi ini dilakukan untuk mempermudah pemrosesan pemberian noise dan filtering. Gambar salah satu citra koin 500 grayscale dapat dilihat pada Gambar 3.

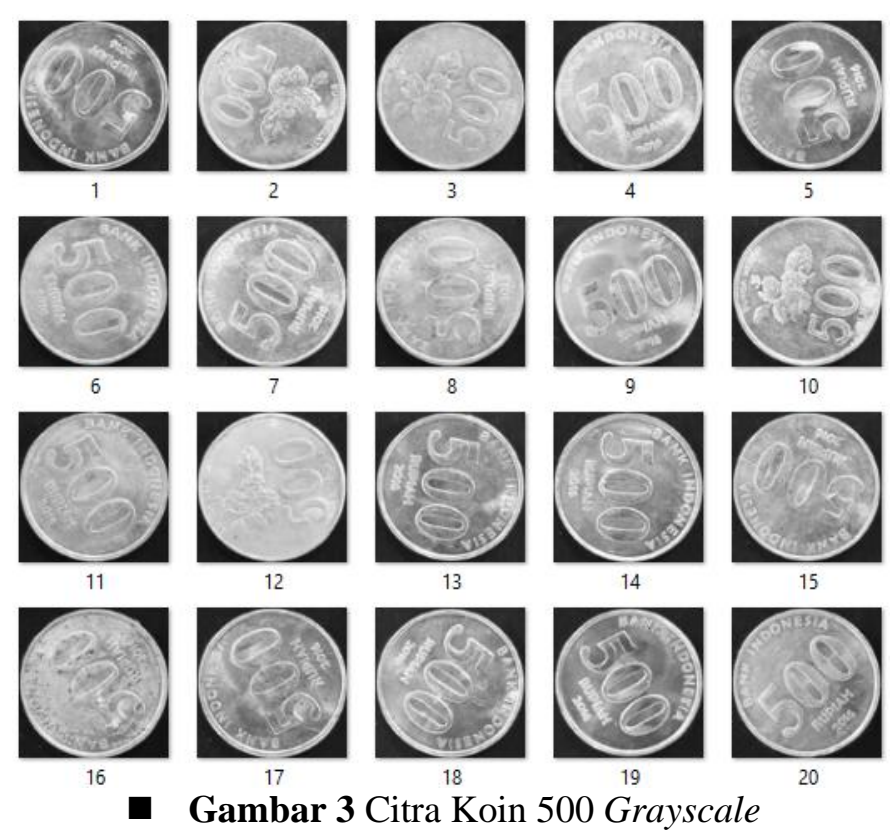

\subsection{Pemberian Derau}

Pemberian derau atau noise dilakukan dengan menggunakan Matlab. Setiap citra koin 500 yang digunakan diberikan 3 buah derau yaitu derau Eksponensial, derau Gaussian, dan derau Salt and pepper. Gambar salah satu citra koin 500 dengan derau Eksponensial dapat dilihat pada Gambar 4. Gambar salah satu citra koin 500 dengan derau Gaussian dapat dilihat pada Gambar 5. Gambar salah satu citra koin 500 dengan derau Salt and pepper dapat dilihat pada Gambar 6.

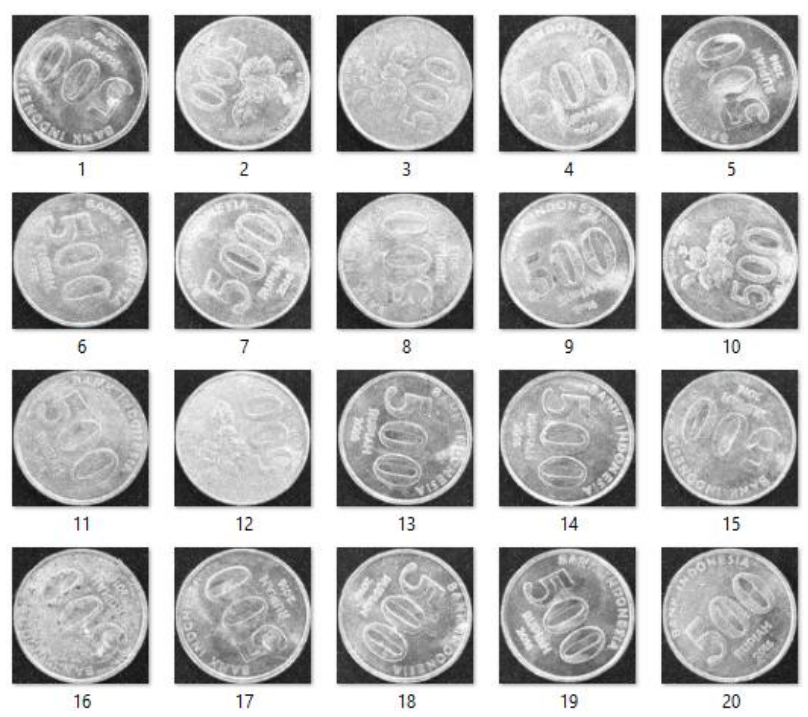

- Gambar 4 Citra Koin 500 dengan Derau Eksponensial 

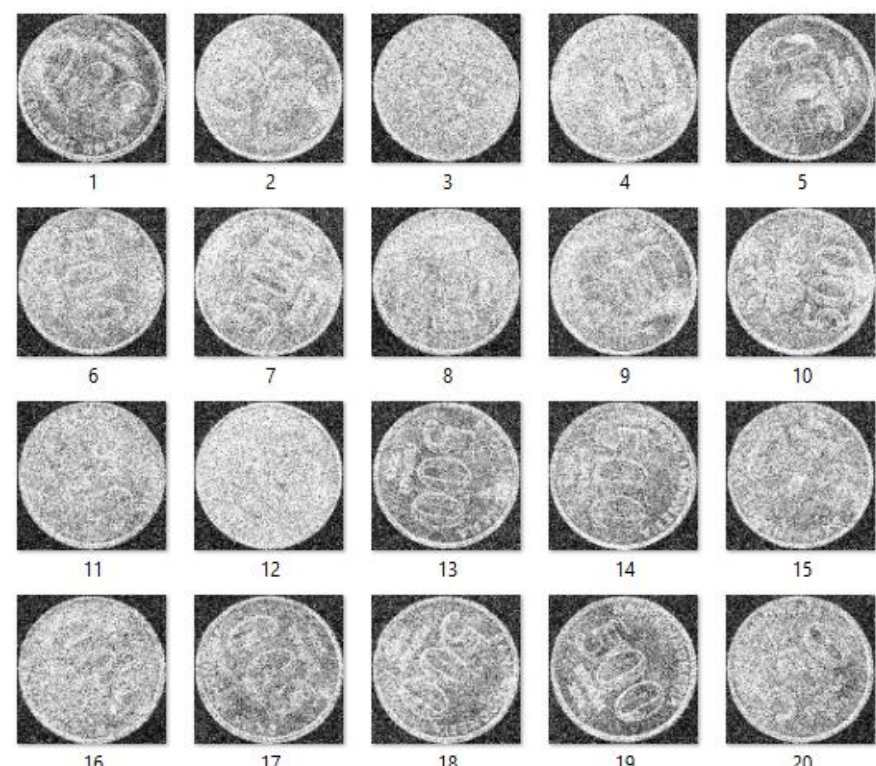

19

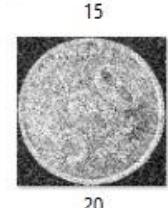

- Gambar 5 Citra Koin 500 dengan Derau Gaussian

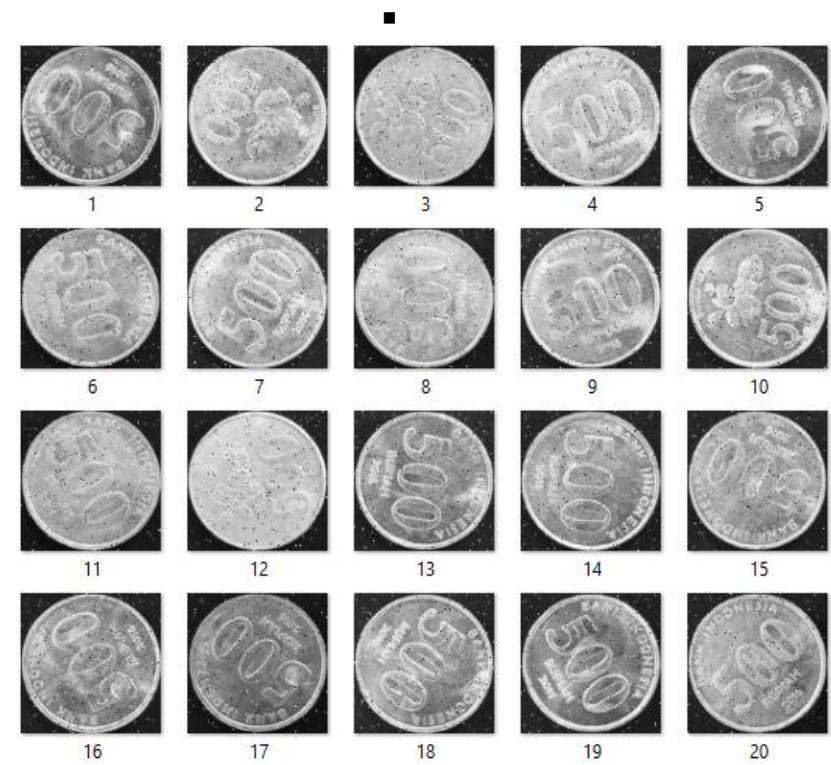

- Gambar 6 Citra Koin 500 dengan Derau Salt and pepper

\subsection{Proses Filtering}

Proses filtering merupakan proses untuk memperbaiki citra yang telah diberikan noise. Setiap citra koin 500 yang diberikkan noise akan diberikan 3 filter yang berbeda yaitu filter Rerata, filter Median, dan filter Wiener.

\subsubsection{Proses Filtering Derau Eksponensial}

Citra koin 500 yang sudah diberikkan derau eksponensial difilter dengan filter yang berbeda. Dari hasil filter akan dicari filter yang terbaik untuk derau eksponensial berdasarkan nilai MSE dan PSNR. Gambar salah satu citra koin 500 dengan derau eksponensial dan filter Rerata dapat dilihat pada Gambar 6. Gambar salah satu citra koin 500 dengan derau eksponensial dan filter Median dapat dilihat pada Gambar 7. Gambar salah satu citra koin 500 dengan derau eksponensial dan filter Wiener dapat dilihat pada Gambar 8.

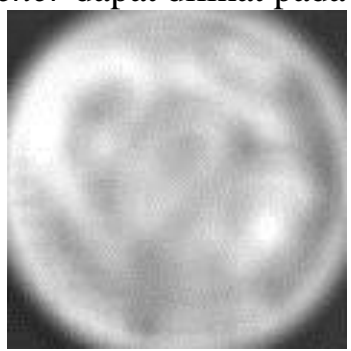

Gambar 7 salah satu citra koin 500 dengan derau eksponensial dan filter Rerata 


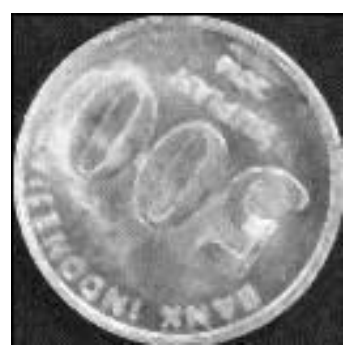

Gambar 8 salah satu citra koin 500 dengan derau eksponensial dan filter Median

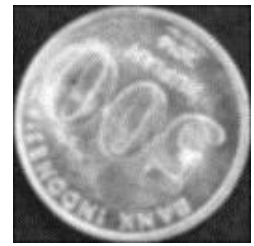

Gambar 9 salah satu citra koin 500 dengan derau eksponensial dan filter Wiener

\subsubsection{Proses Filtering Derau Gaussian}

Citra koin 500 yang sudah diberikkan derau Gaussian difilter dengan filter yang berbeda. Dari hasil filter akan dicari filter yang terbaik untuk derau Gaussian berdasarkan nilai MSE dan PSNR. Gambar salah satu citra koin 500 dengan derau Gaussian dan filter Rerata dapat dilihat pada Gambar 9. Gambar salah satu citra koin 500 dengan derau Gaussian dan filter Median dapat dilihat pada Gambar 10. Gambar salah satu citra koin 500 dengan derau Gaussian dan filter Wiener dapat dilihat pada Gambar 11.

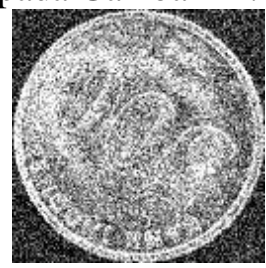

- Gambar 10 salah satu citra koin 500 dengan derau Gaussian dan filter Rerata

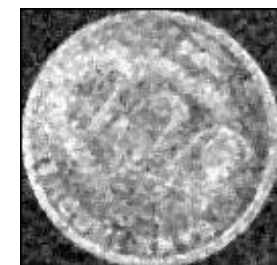

- Gambar 11 salah satu citra koin 500 dengan derau Gaussian dan filter Median

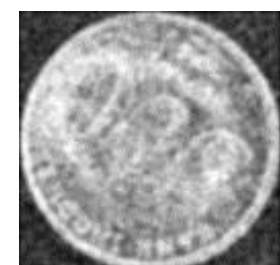

- Gambar 12 salah satu citra koin 500 dengan derau Gaussian dan filter Wiener

\subsubsection{Proses Filtering Derau Salt and pepper}

Citra koin 500 yang sudah diberikkan derau Salt and pepper difilter dengan filter yang berbeda. Dari hasil filter akan dicari filter yang terbaik untuk derau Salt and pepper berdasarkan nilai MSE dan PSNR. Gambar salah satu citra koin 500 dengan derau Salt and pepper dan filter Rerata dapat dilihat pada Gambar 12. Gambar salah satu citra koin 500 dengan derau Salt and pepper dan filter Median dapat dilihat pada Gambar 13. Gambar salah satu citra koin 500 dengan derau Salt and pepper dan filter Wiener dapat dilihat pada Gambar 14. 


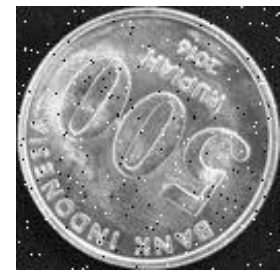

Gambar 13 salah satu citra koin 500 dengan derau Salt and pepper dan filter Rerata

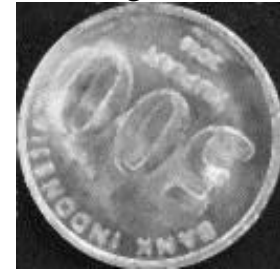

Gambar 14 salah satu citra koin 500 dengan derau Salt and pepper dan filter Median

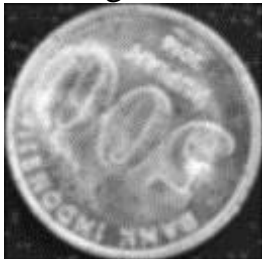

Gambar 15 salah satu citra koin 500 dengan derau Salt and pepper dan filter Wiener

\subsection{Menghitung MSE dan PSNR}

Menghitung MSE dan PSNR dilakukan menggunakan fungsi pada Matlab. Setiap citra koin 500 yang sudah difilter, dibandingkan dengan citra koin 500 grayscale untuk mendapatkan nilai MSE dan PSNR.

\section{Hasil Dan Penelitian}

Berikut merupakan perbandingan nilai MSE pada citra koin 500 dalam bentuk grafik. Gambar grafik perbandingan nilai MSE Derau Gaussian dengan filter Rerata, Median, dan Wiener dapat dilihat pada Gambar 15. Gambar grafik perbandingan nilai MSE Derau Eksponensial dengan filter Rerata, Median, dan Wiener dapat dilihat pada Gambar 16. Gambar grafik perbandingan nilai MSE derau Salt and Pepper dengan filter Rerata, Median, dan Wiener dapat dilihat pada Gambar 17.

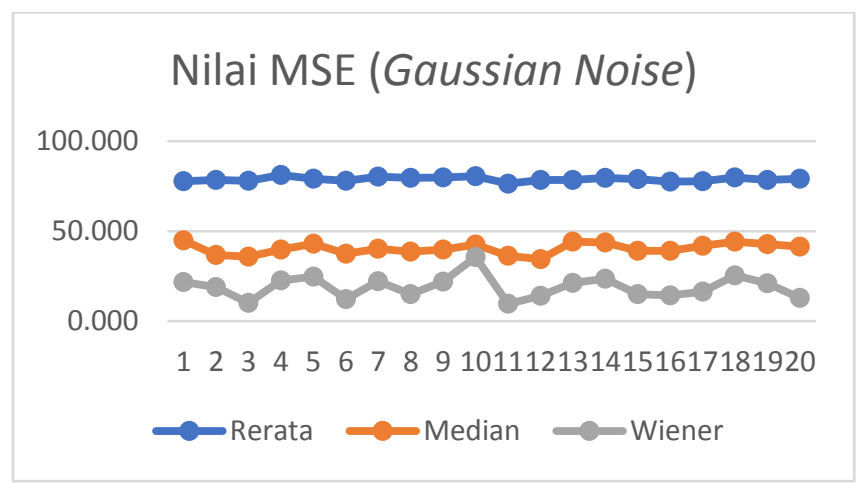

- Gambar 16 Grafik Perbandingan Nilai MSE Derau Gaussian dengan Filter Rerata, Median, dan Wiener

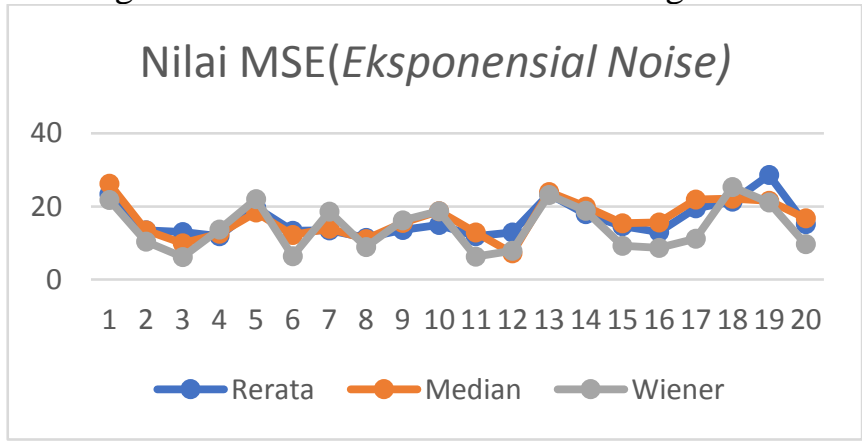

- Gambar 17 Grafik Perbandingan Nilai MSE Derau Eksponensial dengan Filter Rerata, Median, dan Wiener 


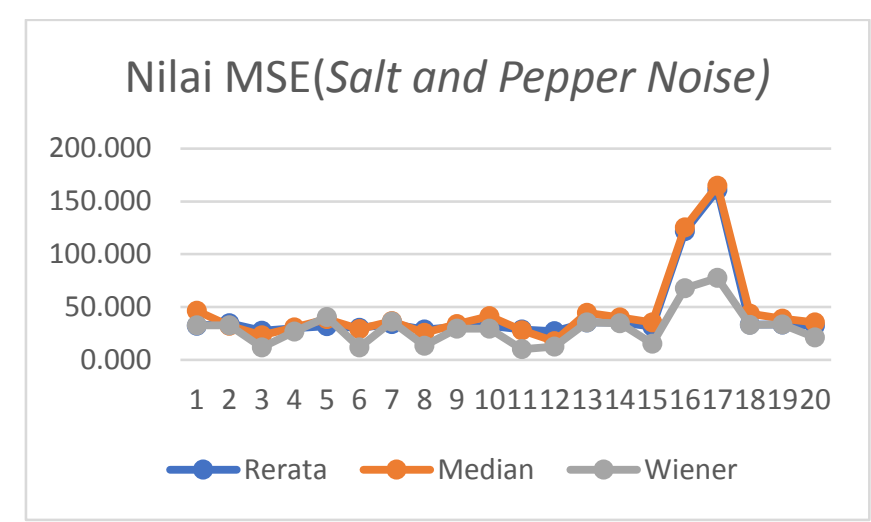

- Gambar 18 Grafik Perbandingan Nilai MSE Derau Salt and Pepper dengan Filter Rerata, Median, dan Wiener

Berikut merupakan perbandingan nilai PSNR pada citra koin 500 dalam bentuk grafik. Gambar grafik perbandingan nilai PSNR Derau Gaussian dengan filter Rerata, Median, dan Wiener dapat dilihat pada Gambar 18. Gambar grafik perbandingan nilai PSNR Derau Eksponensial dengan filter Rerata, Median, dan Wiener dapat dilihat pada Gambar 19. Gambar grafik perbandingan nilai PSNR Derau Salt and Pepper dengan filter Rerata, Median, dan Wiener dapat dilihat pada Gambar 20.

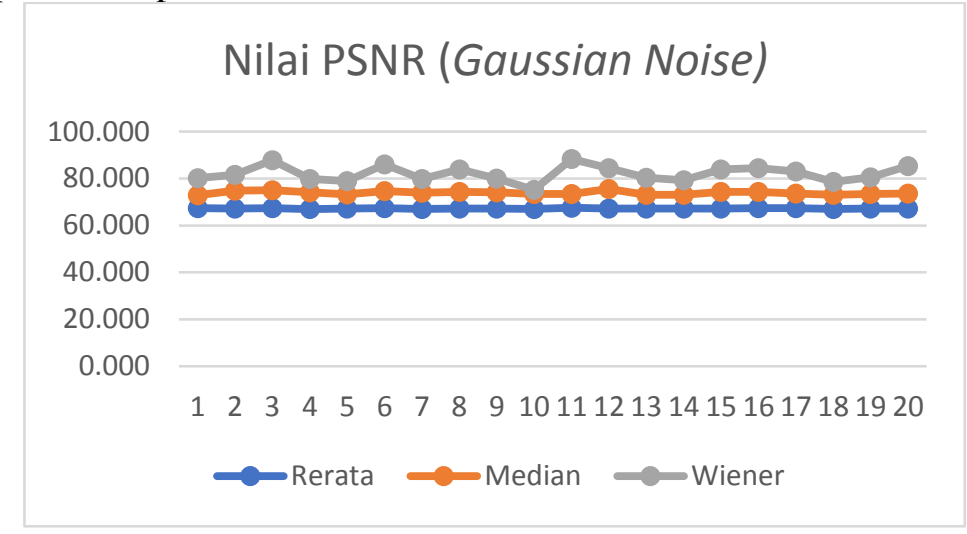

Gambar 19 Grafik Perbandingan Nilai PSNR Derau Gaussian dengan Filter Rerata, Median, dan Wiener

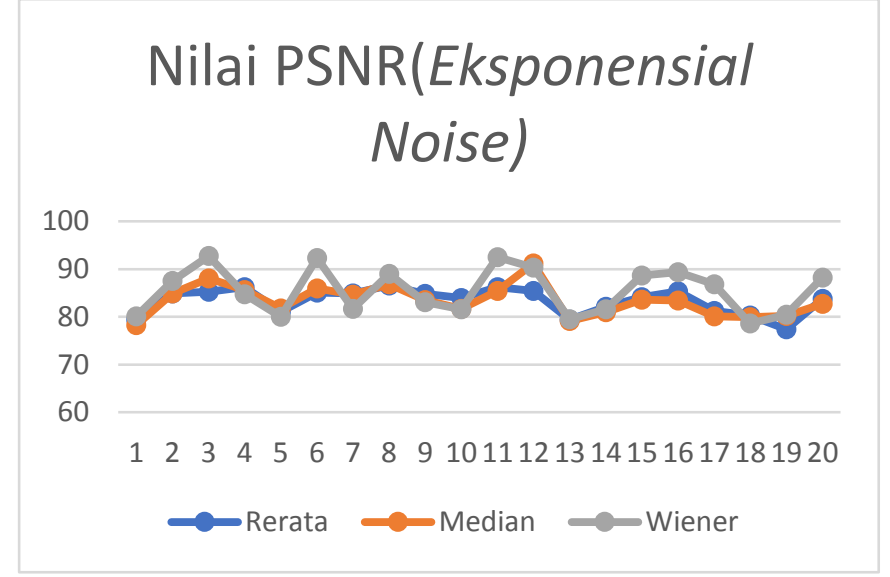

- Gambar 20 Grafik Perbandingan Nilai PSNR Derau Eksponensial dengan Filter Rerata, Median, dan Wiener 


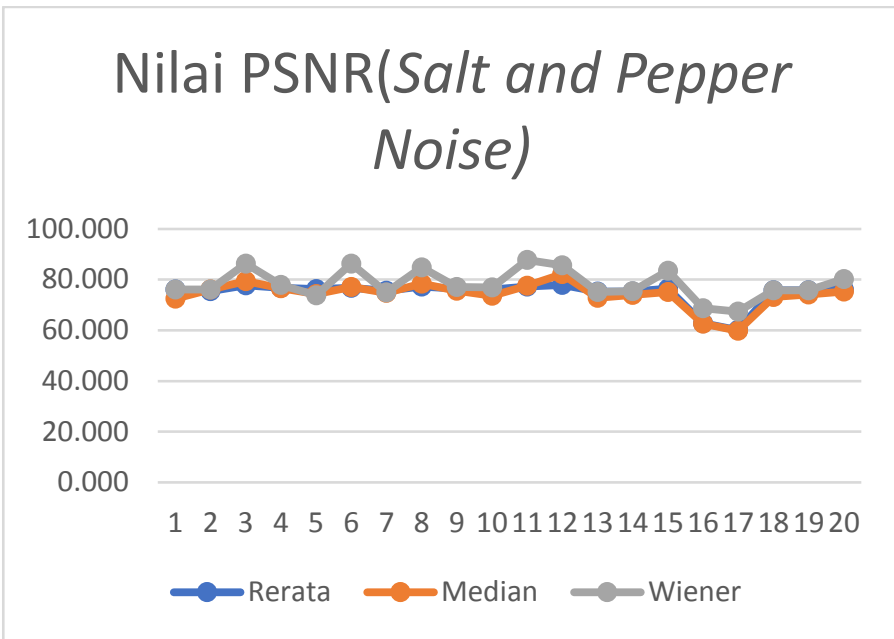

- Gambar 21 Grafik Perbandingan Nilai PSNR Derau Salt and Pepper dengan Filter Rerata, Median, dan Wiener

\section{Analisis Data Filtering}

Grafik perbandingan nilai MSE derau Gaussian dengan filter Rerata, Median, dan Wiener menunjukkan filter Wiener mempunyai nilai MSE terkecil dibandingkan filter Rerata dan filter Median.

- $\quad$ Grafik perbandingan nilai MSE derau Eksponensial dengan filter Rerata, Median, dan Wiener menunjukkan filter Wiener mempunyai nilai rata-rata MSE terkecil dibandingkan filter Rerata dan filter Median.

- Grafik perbandingan nilai MSE derau Salt and peper dengan filter Rerata, Median, dan Wiener menunjukkan filter Wiener mempunyai nilai MSE terkecil dibandingkan filter Rerata dan filter Median.

- $\quad$ Semakin kecil nilai MSE yang dihasilkan oleh setiap filter, maka semakin besar nilai PSNR yang didapatkan.

\section{KESIMPULAN}

- Filter Wiener adalah filter yang terbaik untuk digunakkan pada citra yang memiliki derau Eksponensial dibandingkan dengan filter Rerata dan Median.

- $\quad$ Filter Wiener adalah filter yang terbaik untuk digunakkan pada citra yang memiliki derau Gaussian dibandingkan dengan filter Rerata dan Median.

- Filter Wiener adalah filter yang terbaik untuk digunakkan pada citra yang memiliki derau Salt and Pepper dibandingkan dengan filter Rerata dan Median.

Pada selanjutnya penilaian kualitas citra dapat dilakukan dengan metode yang berbasis visual dengan pembagian kuesioner mengenai kualitas dari citra yang dianalisis.

\section{DAFTAR PUSTAKA}

[1] S. N. Syarifuddin, " Analisis Filtering Citra dengan Metode Mean Filter dan Median Filter", Jurnal Teknik Informatika Universitas Komputer Indonesia, Vol. 12, no. 2, pp. 107-115, 2012.

[2] B. H. Sholihin dan R. Aprias, "Perbaikan Citra dengan Menggunakan Median Filter dan Metode Histogram Equalization", Jurnal T. Elektro UMS, Vol. 14, no. 2, pp. 67-74, 2014.

[3] A. Wedianto, H. L. Sari, dan Y. Suzantri, "Analisa Perbandingan Metode Filter Gaussian, Mean dan Median Terhadap Reduksi Noise”, Jurnal Media Infotama, Vol.12, No.1, pp. 21-30, 2016.

[4] I. B. Setiawan, T. A. S. Prasida, dan M. Bezaleel, "Aplikasi Noise Reduction untuk Perbaikan Kualitas Suara pada Data Audio Menggunakan Algoritma FastICA”, Jurnal Teknologi Informasi-Aiti, Vol. 8, No. 2, pp 190-200, 2011.

[5] N. Fuad dan Y. Melita, "Analisa Hasil Perbandingan Metode Low-Pass Filter Dengan Median Filter untuk Optimalisasi Kualitas Citra Digital”, Jurnal Teknika, Vol. 4, No. 2, pp 395-400, 2012 